\title{
Recent Developments in Bacterial Cold-Shock Response
}

\author{
Sangita Phadtare* \\ Department of Biochemistry, Robert Wood Johnson \\ Medical School, 675 Hoes Lane, Piscataway, New Jersey \\ 08854, USA
}

\begin{abstract}
In response to temperature downshift, a number of changes occur in cellular physiology such as, (i) decrease in membrane fluidity, (ii) stabilization of secondary structures of nucleic acids leading to reduced efficiency of mRNA translation and transcription, (iii) inefficient folding of some proteins, and (iv) hampered ribosome function. Cold-shock response and adaptation has been quite extensively studied in Escherichia coli and Bacillus subtilis. A number of cold shock proteins are induced to counteract these harmful effects of temperature downshift. General principles of cold-shock response along with recent findings on desaturase system, RNA chaperone and transcription antitermination function of CspA homologues, cold shock induction of chaperones and synthesis of trehalose, CspA homologues from hyperthermophilic bacteria and possible multiple roles of cold shock proteins in other stress responses of bacteria are discussed.
\end{abstract}

\section{Introduction}

Temperature is one of the major stresses that all the living organisms have to face. Heat-shock response from bacteria to human has been extensively studied, while cold-shock response has caught attention of researchers relatively recently. A major reason why heat shock is extensively studied is because it causes well-defined damage to the cells, i.e. unfolding or denaturation of proteins. Heatshock-induced proteins, chaperones, assist in protein folding. In contrast, cold shock does not cause such well-defined cellular damage. Cold-shock response is classically exhibited when an exponentially growing culture is shifted from its optimum growth temperature to a lower temperature. In case of majority of bacteria such as Escherichia coli, upon temperature downshift, there is a transient arrest of cell growth, during which general protein synthesis is severely inhibited. However, synthesis of a number of proteins, called cold-shock proteins, is induced under these conditions. Eventually, the synthesis of these proteins decreases, cells become acclimated to low temperature and growth resumes (Jones et al., 1987). The effect of cold shock is seen at multiple levels such as; (i) decrease in the membrane fluidity affecting the membraneassociated functions such as active transport and protein secretion, (ii) stabilization of the secondary structures of RNA and DNA, leading to reduced efficiency of mRNA translation and transcription, (iii) slow or inefficient folding of some proteins and (iv) ribosomes need to be cold-adapted to function properly at low temperature.

The study of cold-shock response is now in limelight because of its commercial and health implications. Table 1 illustrates how studies on bacterial cold-shock response are useful in avoiding potentially disastrous situations in various industries. Understanding cold-shock response of food-borne pathogens such as Listeria is imperative as refrigeration is a commonly used method of food storage. Cells, which are cold-shocked prior to freezing, exhibit better cryotolerance. Therefore, food-spoilage bacteria can be sensitized to damage caused by cold temperatures through direct freezing of the food articles (Willimsky et al.,

\begin{tabular}{|c|c|c|}
\hline Industry & Concern & Solution \\
\hline \multirow[t]{2}{*}{ Food } & $\begin{array}{l}\text { Spoilage of refrigerated food and infections due to food-borne } \\
\text { pathogens }\end{array}$ & $\begin{array}{l}\text { Reduce efficiency of cold- shock response of food- borne } \\
\text { pathogens }\end{array}$ \\
\hline & $\begin{array}{l}\text { Instability of lactic acid bacteria starter cultures due to temperature } \\
\text { changes during fermentations in dairy industry }\end{array}$ & $\begin{array}{l}\text { Modify starter cultures to improve cold adaptation and } \\
\text { cryotolerance }\end{array}$ \\
\hline \multirow[t]{2}{*}{ Agriculture } & Reduced efficiency of 'biofertilizers' due to low temperatures & Use of cold-adapted Rhizobial cultures \\
\hline & $\begin{array}{l}\text { Great economic losses due to low tolerance of plants to low } \\
\text { temperatures }\end{array}$ & $\begin{array}{l}\text { Enhance chilling resistance of plants using gene transfer from } \\
\text { bacteria to plants }\end{array}$ \\
\hline \multirow[t]{2}{*}{ Research } & $\begin{array}{l}\text { Inefficient expression of proteins due to temperature sensitivity or } \\
\text { proteolysis }\end{array}$ & $\begin{array}{l}\text { Cold-inducible expression systems for production of these } \\
\text { proteins }\end{array}$ \\
\hline & $\begin{array}{l}\text { Reduced efficiency of certain processes using biocatalysts at low } \\
\text { temperatures }\end{array}$ & Use of cold-adapted enzymes \\
\hline
\end{tabular}

*For correspondence. Email phadtasa@umdnj.edu. 
1992). In the same token, cryotolerance of useful bacteria such as lactic acid bacteria can be improved, so that economic losses resulting from reduced starter culture's activity/viability due to harsh temperature changes in the fermentation processes are minimized. Recently, the desC gene for the acyl-lipid desaturase from the thermophilic cyanobacterium Synechococcus vulcanus was introduced into Nicotiana tabacum. As a result, the lipid content, the extent of fatty acid unsaturation and chilling tolerance of these plants significantly increased. Seeds of plants that expressed the desC gene also demonstrated higher chilling tolerance than those of the control plants (Ishizaki-Nishizawa et al., 1996; Orlova et al., 2003). Certain proteins are not produced efficiently at $37^{\circ} \mathrm{C}$. These can be overproduced in large quantities at low temperatures using cold-inducible promoters, for example, the promoter of $\operatorname{csp} A$, encoding the major cold shock protein of $E$. coli. This will prove to be a very powerful tool in biotechnology (Baneyx and Mujacic, 2003; Vasina and Baneyx, 1997). This will be useful in not only producing proteins for structural determination, but also proteins of medical importance.

Recently, certain aspects of bacterial cold-shock response such as regulation of expression of CspA homologues have been extensively reviewed (for review see Ermolenko and Makhatadze, 2002; Gualerzi et al., 2003; Phadtare et al., 1999; Phadtare, 2000; Weber and Marahiel, 2003; Yamanaka et al., 1998). Aside from summarizing the general principles underlying this response, this article will mainly focus on the recent developments in cold shock response, with emphasis on E. coli.

\section{General principles of cold-shock response}

Bacteria sense the change in temperature mainly at level of cell membrane, nucleic acid and ribosomes (Phadtare, 2000). The changes in cell membrane are discussed in detail later in this article. Various environmental factors such as changes in temperature or osmolarity, exposure to chemicals can change the extent of DNA supercoiling, which in turn affects the expression of various genes. The supercoiling of DNA is presumed to act as a thermosensor and its regulation is important in order to maintain the DNA related functions, such as replication, transcription and recombination (Drlica, 1992; Higgins et al., 1988). The usual negative supercoiling state of DNA transiently increases after the temperature downshift (Krispin and Allmansberger, 1995; Mizushima et al., 1997). The arrangement between the -10 and -35 region of many promoters is affected due to this change, which in turn affects recognition of some $\sigma^{70}$ promoters, for example, the cold-shock-inducible E. coli recA promoter is one such twist-sensitive promoter (Wang and Syvanen, 1992). It is hypothesized that organisms sense the changes in temperature also at the level of ribosomes (VanBogelen and Neidhardt, 1990). It was shown that artificially induced high levels of the guanosine $5^{\prime}$ triphosphate-3'diphosphate (pppGpp) and guanosine $5^{\prime}$ diphosphate-3'diphosphate (ppGpp) (collectively abbreviated as (p)ppGpp) diminish the expression of cold-shock proteins, while low concentration increases their production. Thus, ( $p$ )ppGpp affect the magnitude of the cold-shock response (Jones et al., 1992).

\section{Cold shock proteins}

One of the most prominent responses of the microorganisms to cold shock is induction of cold shock proteins. All the three groups of microorganisms, i. e. psychrophiles, mesophiles and thermophiles, synthesize cold shock proteins to counteract the effect of temperature downshift. The cold-shock response and cold shock proteins have been studied in detail using E. coli and Bacillus subtilis as model systems (for review see Ermolenko and Makhatadze, 2002; Phadtare et al., 1999; Phadtare, 2000; Weber and Marahiel, 2003; Yamanaka et al., 1998).

The cold shock proteins of $E$. coli include; group I: CspA (Goldstein et al., 1990), CspB (Lee et al., 1994), CspG (Nakashima et al., 1996), Cspl (Wang et al., 1999), CsdA (Toone et al., 1991), RbfA (Dammel and Noller, 1995), NusA (Friedman et al., 1984), PNP (Donovan and Kushner, 1986), and group II: RecA (Walker, 1984), IF-2 (Gualerzi and Pon, 1990), H-NS (Dersch et al., 1994), GyrA (Sugino et al., 1977), Hsc66, HscB (Lelivelt and Kawula, 1995), dihydrolipoamide transferase and pyruvate dehydrogenase (Jones and Inouye, 1994). The induction levels of these proteins vary, proteins belonging to group I being more dramatically induced than those from group II. CspA, CspB, CspG and Cspl have been proposed to function as RNA chaperones; CsdA is a ribosomal associated protein with RNA unwinding activity. RbfA is a ribosomal binding factor, recently shown to be involved in maturation of ribosomes at low temperatures (Xia et al., 2003). NusA is involved in termination and antitermination of transcription and PNP is a ribonuclease. PNP selectively degrades $\operatorname{csp} A \mathrm{mRNA}$ at $15^{\circ} \mathrm{C}$ and represses production of CspA homologues at the end of the lag phase (Neuhaus et al., 2000; Yamanaka and Inouye, 2001a). A recent DNA microarray analysis of a PNP-deficient mutant showed that this enzyme may have a complex role in controlling cold adaptation of cells. Along with csp genes, genes previously not reported to be associated with cold shock response such as rpoE and rse $A$ increased upon cold shock in this mutant (Polissi et al., 2003). In the case of Pseudomonas putida, deletion of the pnp gene did not lead to cold sensitivity and the transcription pattern of pnp upon cold shock in this organism was markedly different from that in E. coli. It thus appears that regulation of expression of pnp and its physiological role in cold shock response may be different in different bacterial species (Favaro and Deho, 2003). RecA and IF2 are recombination and initiation factors, respectively. H-NS is a nucleoid-associated, DNA-binding protein and GyrA is the subunit of topoisomearse DNA gyrase. Recently, more cold-shock-inducible proteins have been reported. A trigger factor (TF) enhances viability of cells at low temperature and is induced after a lag period of 2-3 h upon cold shock (Kandror and Goldberg, 1997). It presumably helps protein synthesis and folding to continue at low temperature, and may also help to maintain preexisting proteins in a functional form by promoting refolding of cold-damaged proteins. A ribosome-associated protein of $E$. coli, pY is also induced by temperature downshift. Ribosomes from bacterial cells growing at a normal physiological temperature do not contain $\mathrm{pY}$, whereas a temperature downshift results in the appearance of this protein in ribosomes. It also appears in the ribosomes of those 
cells that have reached the stationary phase of growth at a physiological temperature. It inhibits translation at the elongation stage by blocking binding of aminoacyl-tRNA to the ribosomal A site (Agafonov et al., 2001). In addition, trehalose-6-phosphate synthase (OtsA) and trehalose-6phosphate phosphatase (OtsB) are also induced by cold shock in E. coli (Kandror et al., 2002).

In case of $B$. subtilis, three CspA homologues CspB, CspC and CspD were shown to be essential for efficient growth at optimal temperature, for efficient adaptation to low temperatures and survival during stationary phase (Graumann et al., 1997). In addition to these, other proteins that are induced after temperature downshift include: CheY (chemotaxis), Hpr (sugar uptake), ribosomal proteins S6 and L7/ L12 (translation), peptidyl propyl cis/ trans isomerase (protein folding), cysteine synthase, ketolacid reductoisomerase, glyceraldehyde dehydrogenase, and triosephosphate isomerase (general metabolism) (Graumann et al., 1996; Graumann and Marahiel, 1999).

\section{CspA family of cold shock proteins}

The first cold-shock protein, CspA, was reported from $E$. coli and its homologues have been reported from a number of gram-positive and gram-negative bacteria, but not from archaea and cyanobacteria. The CspA family of $E$. coli consists of nine homologous proteins, CspA to Cspl, but among them only CspA, CspB, CspG and Cspl are cold-shock inducible. The functions of the CspA family members overlap since they are able to substitute for each other during cold acclimation. E. coli cells harboring double or triple deletions of the csp genes $(\Delta \operatorname{csp} A \Delta \operatorname{csp} B, \Delta \operatorname{csp} A \Delta \operatorname{csp} G, \Delta \operatorname{csp} B \Delta c s p G, \Delta c s p A \Delta c s p /$ or $\Delta \operatorname{csp} A \Delta \operatorname{csp} B \Delta c s p G$ ) are not cold sensitive, and in the triple deletion strain, CspE is overproduced at low temperatures. On the other hand, a quadruple deletion strain $(\Delta \operatorname{csp} A \Delta \operatorname{csp} B \Delta \operatorname{csp} G \Delta c s p E)$ is cold-sensitive, and this defect can be complemented by overproduction of any one of CspA homologues except CspD (Xia et al., 2001a). In contrast, in the case of $B$. subtilis, however, a cspB/cspC/ $\operatorname{csp} D$ triple deletion mutation is lethal, indicating that at least one CspA homologue is essential for the survival of the organism, CspB being the most important of the three proteins (Graumann et al., 1997).

Regulation of expression of cold-shock induction of CspA and its homologues occurs at levels of transcription, mRNA stability and translation and has been a topic of extensive studies. The cold-shock induction of $\operatorname{csp} A$ does not need any additional transcription factors in contrast to heat-shock induction of proteins. One of the unique features of $\operatorname{csp} A, \operatorname{csp} B, \operatorname{csp} G$ and $\operatorname{cspl}$ is the unusually long 5 ' untranslated region (5'-UTR). The 5'-UTR contains a highly conserved unique 11-base sequence called the cold box (Jiang et al., 1996; Xia et al., 2001b). It is a presumed transcriptional pausing site and is involved in the repression of $\operatorname{csp} A$ expression. Based on deletion analysis, $\operatorname{csp} A 5^{\prime}-\mathrm{UTR}$ is presumed to be responsible for the extreme instability of $\operatorname{cspA} \mathrm{mRNA}$ at $37^{\circ} \mathrm{C}$, and has positive effect on mRNA stabilization at low temperature (Mitta et al., 1997). CspA mRNA is dramatically but transiently stabilized (half-life more than $20 \mathrm{~min}$ at 15 ${ }^{\circ} \mathrm{C}$ as compared to half life of $12 \mathrm{~s}$ at $37^{\circ} \mathrm{C}$ ) immediately following cold shock. Its promoter is active at $37^{\circ} \mathrm{C}$, but due to instability of its mRNA, CspA is hardly detected at $37^{\circ} \mathrm{C}$. Interestingly, CspA is also produced at $37^{\circ} \mathrm{C}$ during early exponential growth phase and its mRNA becomes unstable by mid- to late-exponential growth phase (Brandi et al., 1999). This expression is attributed to the position of $\operatorname{cspA}$ near oriC resulting in higher gene dosage effect, and high concentration of its transcription activator Fis and higher stability of its mRNA due to lower RNase activity. With increasing cell density, Fis is diluted out, while, a transcriptional repressor, $\mathrm{H}-\mathrm{NS}$, accumulates leading to decline in level of $\operatorname{csp} A$ transcript. This is followed by rapid disappearance of the cspA mRNA due to increased rate of its degradation at $37^{\circ} \mathrm{C}$ (Brandi et al., 1999). Later it was shown that production of $\mathrm{CspA}$ at $37^{\circ} \mathrm{C}$ during early exponential growth phase was due to nutritional upshift and the induction level of CspA at $37^{\circ} \mathrm{C}$ was one-sixth of its cold shock induction level (Yamanaka and Inouye, 2001b).

The cspA mRNA contains a unique sequence located 14-bases downstream of the initiation codon. This element is also present in CspB, CspG, Cspl, CsdA and RbfA and presumed to enhance translation initiation in cold shock mRNAs. It was originally termed as the downstream box (DB). It is complementary to a region in the penultimate stem of $16 S$ rRNA and was initially thought to enhance translation initiation by facilitating the formation of translation preinitiation complex through binding to $16 \mathrm{~S}$ rRNA, however this view is disputed and the exact mechanism of the enhancing effect on translation initiation by DB is unknown at present (Mitta et al., 1997; Moll et al., 2001).

\section{Psychrophilic bacteria}

The cold-shock response of psychrophiles is distinct from that of mesophiles (Hebraud and Potier, 1999). Mesophilic bacteria, with the exception of Enterococcus faecalis do not produce Caps (cold acclimation proteins) in response to continuous growth at low temperature (Panoff et al., 1997). In psychrophilic bacteria, the synthesis of housekeeping proteins is not repressed following an abrupt temperature downshift, a large number of cold shock proteins are synthesized at relatively moderate levels and synthesis of Caps is prolonged. Two psychrophiles, namely Arthrobactor globiformis (Berger et al., 1996; Berger et al., 1997) and $P$. fragi (Michel et al., 1997) are well studied with respect to their cold-shock response. A low-temperature-specific proteolytic system has been described for A. globiformis that presumably eliminates denatured proteins whose accumulation can be detrimental to the cells.

\section{Cyanobacteria}

Cyanobacteria, the photosynthetic bacteria lack CspA homologues, but they have a family of cold-inducible, RNA-binding proteins (Rbp) (Sato, 1995). These are similar to eukaryotic RNA-binding proteins. These belong to the RBD (RNA-binding domain) family of proteins, and are structurally distinct from the CSD (cold-shock domain) family of proteins. In addition, Clp proteins, S21 protein in the small subunit of ribosome and CrhC, an RNA helicase are also induced by temperature downshift in cyanobacteria 
(Chamot et al., 1999; Chamot and Owttrim, 2000; Los and Murata, 1999; Schelin et al., 2002). A membrane-bound histidine kinase, Hik33, was identified as a cold sensor in Synechocystis and it was postulated that Hik33 might detect decrease in temperature by sensing the rigidification of membrane lipids (Suzuki et al., 2000). A 'knockout' library of cells that lacked the activities of individual histidine kinases was constructed by systematically disrupting all the putative genes for histidine kinases in Synechocystis. One of the 41 histidine kinases was then identified as a cold sensor. Mutation of the gene for this histidine kinase, Hik33, diminished the extent of induction of several cold-inducible genes, such as the des $D$ gene and the crh gene for RNA helicase. This suggested role of Hik33 in perceiving and transducing cold signal to regulate the expression of coldinducible genes. The desaturase system of cyanobacteria is discussed in detail later in this article.

\section{Current issues in cold-shock response}

\section{Desaturase system}

The desaturase system of Bacillus and cyanobacteria has been reviewed and it is suggested that the expression of cold-inducible genes is regulated by a two-component system and the cold sensors are membrane-bound histidine kinases (Sakamoto and Murata, 2002).

\section{Desaturase system of Bacillus}

The elastic liquid crystalline nature of the cell membrane changes to a gel-phase state upon temperature downshift. Bacteria adapt to this change by either increasing the proportion of unsaturated fatty acids (UFAs) in the membrane lipids, shortening the fatty acid chain length or by altering fatty acid branching from iso to anteiso. The increase in UFA is achieved by two distinct mechanisms. In E. coli the enzyme $\beta$-ketoacyl-acyl carrier protein (ACP) synthase II, that is activated (but not induced) upon cold shock, converts palmitoleic acid to cis-vaccenic acid (Garwin and Cronan, 1980; Garwin et al., 1980). On the other hand, the desaturation system in $B$. subtilis is cold inducible. Bacillus is the only non-photosynthetic bacterium in which the presence and cold induction of desaturase is reported (Aguilar et al., 1998; Aguilar et al., 2001). It has also been shown that in $B$. subtilis anteiso-branched fatty acids are prominent after cold shock. After shift to a lower temperature, the ratio of anteiso- to iso-branched fatty acids is dramatically changed, the change being dependent on the presence of isoleucine or precursors of anteisobranched fatty acids. Anteiso- fatty acids have lower melting point than iso- fatty acids (Kaneda, 1967, 1991). Similar system was also reported from $L$. monocytogenes (Annous et al., 1997).

As mentioned above, Bacillus is the only nonphotosynthetic bacterium in which the presence and cold induction of desaturase has been reported (Aguilar et al., 1998; Aguilar et al., 2001). The des transcript is hardly detected at $37^{\circ} \mathrm{C}$ and its synthesis is transiently induced (10-15-fold) $4 \mathrm{~h}$ after cold shock. Deletion of des gene does not cause cold-sensitivity in Bacillus growing in a rich medium (Aguilar et al., 1998). However, its deletion causes a severe cold-sensitive phenotype in the absence of isoleucine. The four UFA species of different lengths, branching patterns and positions of the double bond that are found in the wild-type strain are not synthesized in the des deletion mutant. Also, the deletion mutant exhibits significantly altered saturated fatty acid profile at the onset of the stationary phase in the presence of exogenous isoleucine sources. It was reported that during cold shock adaptation, des expression can completely replace the isoleucine-dependent fatty acid branching adaptation mechanism (Weber et al., 2001).

A two-component signal transduction system consisting of a sensor kinase DesK and a response regulator DesR is responsible for the cold shock induction of des gene. DesR binds to a DNA segment from -28 to -77 positions relative to the start site of des gene. UFAs act as negative signaling molecules of des transcription (Aguilar et al., 2001). DesK assumes different signaling states in response to a temperature-induced change in membrane fluidity. This is accomplished by regulating the ratio of kinase to phosphatase activity such that at $37^{\circ} \mathrm{C}$, when membrane lipids are disordered, a phosphatase- dominant state is present. A kinase-dominant state predominates upon an increase in the proportion of ordered membrane lipids after a temperature downshift to $25{ }^{\circ} \mathrm{C}$. DesK has four transmembrane domains, and one or more of these domains may propagate a conformational change across the membrane that is sufficient to significantly alter its activity. This conformational change can be governed by the physical state of the membrane lipid bilayer. The liquid crystalline state of membranes changes to a gel phase state when upon temperature downshift. This change may cause activation of the autokinase activity, resulting in autophosphorylation of a conserved histidine present in the transmitter domain of DesK. The phosphoryl group of histidine can be directly transferred to DesR, which activates transcription of des, resulting in synthesis of Des. The newly synthesized UFAs inhibit des transcription either by favoring DesK dephosphorylation of DesR-P or by causing dissociation of DesR-P from its binding site (Aguilar et al., 2001). It was also shown that exogenous isoleucine sources, as well as its alpha-keto acid derivative, which is a branched-chain fatty acid precursor, negatively regulate the expression of the des gene at $37^{\circ} \mathrm{C}$. Isoleucine affects the signaling state of the DesK sensor protein by dramatically increasing the incorporation of anteiso-branched-chain fatty acids into membrane phospholipids. It was proposed that both a decrease in membrane fluidity at constant temperature and a temperature downshift induce des by the same mechanism. Therefore, the Des pathway may provide a novel mechanism to optimize membrane lipid fluidity at a constant temperature (Cybulski et al., 2002). Recently, two groups have published genome-wide transcriptional analysis of cold-shock response in $B$. subtilis using DNA microarrays (Beckering et al., 2002; Kaan et al., 2002). Both analyses reveal that des is the strongest cold-inducible gene, however the DesKR system is not the cold-triggered regulatory system of global relevance. These studies also confirmed the cold induction of classical coldshock genes $\operatorname{csp} B, \operatorname{csp} C$ and $\operatorname{csp} D$ along with identification of possible new factors involved in cold shock adaptation of $B$. subtilis, namely elongation factor homologue ylaG and the $\sigma^{\mathrm{L}}$-dependent transcriptional activator homologue ypIP (Beckering et al., 2002; Kaan et al., 2002). 
Desaturase system of cyanobacteria In case of cyanobacteria, the change in membrane composition in response to temperature downshift is achieved with help of desaturases. These are acyl-lipid desaturases that introduce double bonds into fatty acids that have been esterified to glycerolipids and are bound to the thylakoid membrane in these bacteria (Murata and Wada, 1995). In the case of Synechococcus sp., the two of the desaturase genes, $\operatorname{des} A$ and $\operatorname{des} B$, are induced after temperature downshift from $38^{\circ} \mathrm{C}$ to $22^{\circ} \mathrm{C}$. Their expression is tightly controlled by a combination of mRNA synthesis and stabilization at low temperature (Sakamoto and Bryant, 1997). Deletion of des causes cold sensitivity, as in these organisms desaturation of lipids is correlated with acclimatization of photosynthetic activity at low temperature. On the other hand, introduction of the $\operatorname{des} A$ gene into the chilling-sensitive cyanobacterium Anacystis nidulans increased the cold resistance of this organism (Wada et al., 1990). These results suggest that desaturases are essential for the cold-shock adaptation of cyanobacteria. It has also been shown that transcription of desA is supported by the energy produced by photosynthesis. Thus, the low temperature-induced desaturation of membrane lipids occurs only in the light, and polyunsaturated fatty acids are important for growth and the ability to tolerate photoinhibition of photosynthesis at low temperature (Gombos et al., 1992, 1994).
Recently, it was reported that disruption of genes for fatty acid desaturases in Synechocystis leads to rigidification of membrane lipids and enhances cold inducibility of gene expression. DNA microarray analysis of wild type and $\operatorname{des} A^{-} / \operatorname{des} D^{-}$cells revealed that three types of cold-inducible genes are evident based on degree of enhancement in cold inducilibity, high, moderate and none. Genes such as heat shock genes, sulfate transport system subunit genes and a histidine kinase gene belong to the first category, while those encoding RNA helicase belong to third category. Hik33, a cold-sensing histidine kinase, regulated the expression of most genes in the second and third group, but of only few genes in the first group, suggesting that the first group genes are regulated by an unidentified cold sensor (Inaba et al., 2003).

\section{CspA homologues as RNA chaperones and transcription} antiterminators

At low temperatures, the secondary structures of RNA stabilize, which presumably slows down (i) transcription elongation and (ii) ribosomal movement on RNA and thus translation. CspA homologues are speculated to function as 'RNA chaperones' as they can destabilize the secondary structures in RNA and thus presumably facilitate transcription and translation (Figure 1). Increased levels of CspA homologues after cold shock may be important for
A

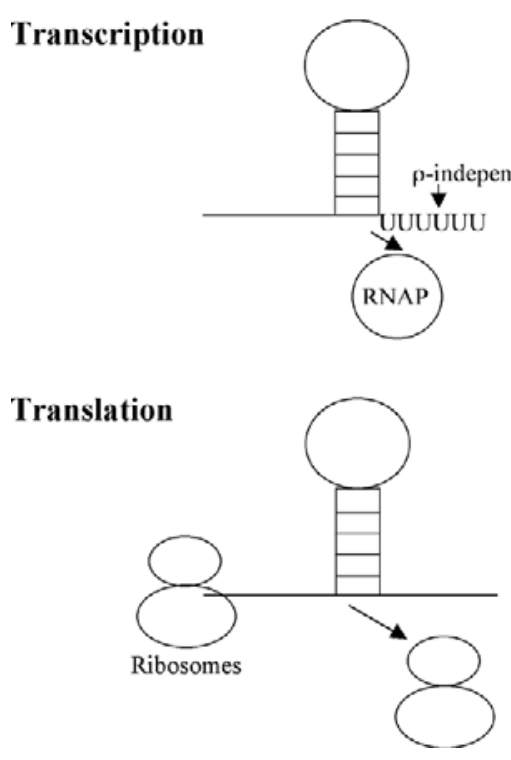

B

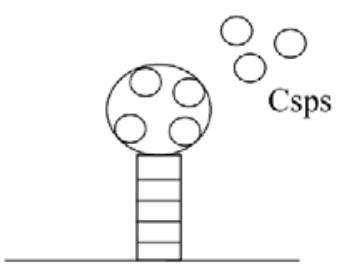

Figure 1. RNA chaperone function of CspA homologues.

A. Schematic representation of inhibition of transcription and translation due to stabilization of secondary structures in RNA upon cold shock. Transcription is terminated when RNA polymerase (RNAP) encounters $\rho$-independent terminator-hairpin loop preceding U-tract and ribosomes fall off RNA when they encounter stem-loop structure, hindering translation. B. Schematic representation of melting of the secondary structure in RNA by CspA homologues. Csp molecules are shown by small circles. The structures are not drawn to scale. 
compensating for higher stability of secondary structures in RNA at low temperatures.

The three-dimensional structure of CspA from E. coli and $\mathrm{CspB}$ from $B$. subtilis has been resolved by X-ray crystallography and NMR-analysis (Feng et al., 1998; Newkirk et al., 1994; Schindelin et al., 1993; Schindelin et al., 1994; Schnuchel et al., 1993). The protein consists of five antiparallel $\beta$-strands, $\beta 1$ to $\beta 5$, forming a $\beta$-barrel structure with two $\beta$-sheets. Two evolutionarily conserved RNA-binding motifs, RNP1 and RNP2, are located on the $\beta 2$ and $\beta 3$ strands. The RNP1 $\mathrm{W}^{11}, \mathrm{~F}^{18}$ and $\mathrm{F}^{20}$, and RNP2 $\mathrm{F}^{31}, \mathrm{H}^{33}$ and $\mathrm{F}^{34}$ form a compact surface-exposed aromatic patch on the three-dimensional structure of $E$. coli CspA. Presumably, the aromatic patch residues contribute to nucleic acid binding by intercalating between DNA or RNA bases. Recently, the binding of CspB from $B$. subtilis to a 25-mer ssDNA was characterized using heteronuclear 2D NMR spectroscopy, which supported the involvement of aromatic patch residues in DNA binding (Zeeb and Balbach, 2003). Several studies involving site-directed mutagenesis of aromatic patch residues have been performed. The results of these studies suggest that substitution of these amino acids with leucine or serine residues destabilize the protein and diminish its RNA binding (Hillier et al., 1998; Schroder et al., 1995). For example, mutations of three phenylalanine residues from the aromatic cluster adversely affect the RNA binding in the case of CspA from E. coli (Hillier et al., 1998). Similarly, in the case of CspB from $B$. subtilis, the nucleic acid binding as well as the protein stability is abolished by the mutations in the two RNP sites (Schindler et al., 1998; Schroder et al., 1995).

CspA from E. coli binds RNA without apparent sequence specificity and with low binding affinity (Jiang et al., 1997). CspB, CspC and CspE from E. coli are able to more selectively bind RNA/single stranded (ss) DNA (the preferred sequences being UUUUU, AGGGAGGGA and $A U$-rich regions, respectively), while $\mathrm{CspB}$ from $B$. subtilis binds to T-rich regions preferentially, however the magnitude of this selectivity is small (Lopez et al., 2001; Phadtare and Inouye, 1999). The non-specific and weak binding of CspA homologues to RNA/ssDNA is also important for the chaperone function, as binding of the protein would not hamper ribosome movement on mRNA. Hence, heat-shock proteins function as protein chaperones at high temperatures, while CspA homologues function as RNA chaperones at low temperatures (Graumann and Marahiel, 1998; Jiang et al., 1997).

E. coli CspE is a homologue of CspA and is mainly produced constitutively at $37^{\circ} \mathrm{C}$. In a strain of $E$. coli in which $\operatorname{csp} A, \operatorname{csp} B$ and $\operatorname{csp} G$ are deleted, CspE level increases upon cold shock and the quadruple deletion strain $(\Delta c s p A \Delta c s p B \Delta c s p G \Delta c s p E)$ is cold sensitive (Xia et al., 2001a). CspE interacts with the nascent RNA in transcription elongation complexes and interferes with Q-mediated transcription antitermination (Hanna and Liu, 1998). The link between function of CspA homologues and transcription regulation was further strengthened by the demonstration that several CspA homologues, including CspC and CspE can act as transcription antiterminators in vivo and in vitro. During cold shock, the expression of several promoter-distal genes of the metY-rpsO operon whose products such as, NusA, IF2, RbfA, and PNP are involved in cold acclimation of cells, is increased at the level of transcription antitermination. Overproduction of either CspA, CspE or CspC leads to similar increase in promoter-distal met $Y$-rpsO operon gene expression even at $37^{\circ} \mathrm{C}$ (Bae et al., 2000). This result provided evidence that transcription antitermination function of cold shock-induced CspA homologues is relevant. In addition to reducing the efficiency of transcription termination on $\rho$-independent terminators, CspA homologues also reduce hairpin-induced transcription pausing (Bae et al., 2000).

Current results demonstrate that nucleic acid melting function of CspA homologues is necessary for cellular adaptation to cold, and are consistent with the idea that their transcription antitermination function is linked to their cold shock function (Phadtare et al., 2002a). In E. coli CspE, the aromatic patch residues, $\operatorname{Trp}^{10}, \mathrm{Phe}^{17}$, $\mathrm{Phe}^{19}, \mathrm{Phe}^{30}, \mathrm{His}^{32}$ and $\mathrm{Phe}^{33}$ were individually substituted with Arg residue (Phadtare et al., 2002a; Phadtare et al., $2002 b)$. Only the mutant proteins harboring substitutions of $\mathrm{Phe}^{17}$, $\mathrm{Phe}^{30}$, and $\mathrm{His}^{32}$ residues located in the center of the aromatic patch, were unable to melt nucleic acids. Since, all three mutants bound RNA as efficiently as the wild-type CspE, the results directly implicated $\mathrm{Phe}^{17}$, $\mathrm{Phe}^{30}$ and $\mathrm{His}^{32}$ in the melting process. The primary interaction between the protein and RNA is probably due to a set of positively charged Lys residues $\left(\mathrm{K}^{4}, \mathrm{~K}^{10}, \mathrm{~K}^{16}, \mathrm{~K}^{28}, \mathrm{~K}^{43}\right.$ and $\mathrm{K}^{60}$ ) that surround the aromatic patch. This primary electrostatic interaction must position CspE such that $\mathrm{Phe}^{17}$, $\mathrm{Phe}^{30}$ and $\mathrm{His}^{32}$ residues can intercalate between the bases and thus initiate separation of the nucleic acid strands. In case of each of the above three mutants, the inability to melt nucleic acids resulted in the inability of CspE mutants to antiterminate transcription and to function in cold acclimation, further strengthening the link between nucleic acid melting activity of CspA homologues, transcription antitermination and cold acclimation (Phadtare et al., 2002a; Phadtare et al., 2002b). Further, our results show that binding of multiple CspE molecules in the singlestranded loop region "triggers" the melting of the stem and there are two intermediates of the melting pathway. Phe ${ }^{17}$ and $\mathrm{Phe}^{30}$ act at the earliest stages of melting, while $\mathrm{His}^{32}$ acts later and is necessary for the propagation of melting (unpublished data).

\section{Low temperature protein chaperones}

Misfolding of proteins and aggregation of misfolded peptides are major problems at high temperatures. Cells have heat-shock-inducible systems to synthesize heatshock proteins. Some of them act as molecular chaperones by assisting in correct protein folding and proteolysis of abnormally folded polypeptides. GroEL is one of the major molecular chaperones, which acts in association with other chaperones such as GroES. In contrast, protein misfolding was previously not considered a major problem upon cold shock. But recent reports suggest that proper folding of proteins as well as refolding of cold-damaged proteins is important after cold shock (Kandror and Goldberg, 1997). A peptidyl prolyl isomerase (trigger factor-TF), that catalyzes the cis/trans isomerization of peptide bonds $\mathrm{N}$-terminal to the proline residue was identified in $E$. coli. This enzyme is induced upon cold shock at a modest level after a growth 
lag period of 2-3 h. Similar to other cold shock proteins, its synthesis is induced after temperature downshift from $37^{\circ} \mathrm{C}$ to $10^{\circ} \mathrm{C}$ or exposure to chloramphenicol. Cells with reduced levels of TF show reduced viability during storage a $4{ }^{\circ} \mathrm{C}$; on the other hand, its overexpression leads to enhanced viability. It was suggested that TF has a 'maintenance and repair' function as it helps protein synthesis and folding to continue at low temperature (Kandror and Goldberg, 1997). It accelerates proline-limited steps in protein folding with a very high efficiency. It associates with ribosomes and influences the folding of newly formed protein chains (Maier et al., 2003). It has been proposed to be the first chaperone to interact with the nascent polypeptide chain as it emerges from the tunnel of the $70 \mathrm{~S}$ ribosome and thus probably plays an important role in co-translational protein folding (Blaha et al., 2003). Its cooperation with other chaperone systems, such as GroELS also strengthens its role as a molecular chaperone (Kandror and Goldberg, 1997). Similarly, a trigger factor was identified in $B$. subtilis, which is involved in protein folding at low temperature (Graumann et al., 1996).

Caseinolytic proteases (Clps) represent a new family of bacterial molecular chaperones that includes proteases that are expressed constitutively in some cases and induced by stress in others (Kessel et al., 1995; Thompson and Maurizi, 1994). These are induced in cyanobacteria after temperature downshift. ClpP1 is induced by cold shock and exposure to UV. Its amount increases 15-fold within $24 \mathrm{~h}$ of the temperature downshift (Porankiewicz et al., 1998). Deletion of its gene leads to severe impairment of growth at low temperatures. ClpB in Synechococcus sp. PCC 7942 was identified initially as a heat-inducible molecular chaperone that is essential for the acquisition of thermotolerance. However, its synthesis is also strongly induced upon cold shock. It has been suggested that $\mathrm{ClpB}$ may renature and solubilize aggregated proteins at low temperatures at which translation is repressed (Porankiewicz and Clarke, 1997).

\section{CspA homologues from hyperthermophilic bacteria}

The hyperthermophilic bacterium Thermotoga maritima has an optimum growth temperature of $80^{\circ} \mathrm{C}$. As this bacterium is capable of metabolizing cellulose and xylan, it is important for generating combustible fuels using renewable carbon and energy sources. T. maritima also has an evolutionary significance as according to phylogenetic analysis based on small subunit ribosomal RNA (SSU rRNA), it is located at one of the deepest and most slowly evolving lineages of Eubacteria (Achenbach-Richter et al., 1987). Analysis of the genomic sequence of $T$. maritima MSB8 revealed that almost one quarter of the genome is archeal in nature (Nelson et al., 1999). The similarity between T. maritima and Archaea is speculated to be due to the shared ancestry of portions of the genome resulting from extensive lateral gene transfer between these organisms, which inhabit similar and unique ecological niche. However, archeal genomes so far sequenced do not show presence of CspA homologues, while T. maritima, has two CspA homologues: TmCspB and TmCspL (Nelson et al., 1999). These are the most thermostable CspA homologues known to date with $\mathrm{T}_{\mathrm{m}}$ values above $80{ }^{\circ} \mathrm{C}$ (Wassenberg et al., 1999).
Recently, TmCspB has been extensively studied, mainly from the structural point of view (Frankenberg et al., 1999; Kremer et al., 2001; Martin et al., 2001; Perl et al., 1998; Perl and Schmid, 2001; Wassenberg et al., 1999; Welker et al., 1999). It has a $\beta$-barrel structure similar to that of E. coli $\mathrm{CspA}$ and $B$. subtilis $\mathrm{CspB}$. It was suggested that $\mathrm{Arg}^{2}$ in $\mathrm{TmCspB}$ forms an ion cluster with several centrally and C-terminally located residues (Kremer et al., 2001). Since an arginine residue in the penultimate $\mathrm{N}$-terminal position is found exclusively in CspA homologues from thermophilic bacteria, it was suggested that the thermostability of $\mathrm{TmCspB}$ is based on this ion cluster (Kremer et al., 2001).

As discussed above, in the case of some of $E$. coli csp genes, an unusually long 5'-untranslated region of their mRNAs (5'-UTR) were shown to be essential for regulation of expression during cold-shock response. For example, the 5'-UTR of E. coli $\operatorname{csp} A$ influences the stability of its own mRNA, and increased transcription of this region led to a prolonged cold-shock response (Mitta et al., 1997). Interestingly, TmcspB also contains a long 5 '-UTR and thus, it was suggested that TmCspB may be cold-inducible (Welker et al., 1999). In a recent study it was shown that both $T m C$ spB and TmCspL are able to perform essential functions of $E$. coli CspE in vitro and in vivo, at conditions 50 to $65^{\circ} \mathrm{C}$ below the temperature optimum of T. maritima. They are also able to help cold-acclimatization of $E$. coli cells and in this aspect, resemble their mesophilic counterparts suggesting that their functions in T. maritima may be similar and/or identical. Most importantly, they can antiterminate transcription with $T$. maritima RNA polymerase at $55^{\circ} \mathrm{C}$, the lower limit of temperature range for growth of $T$. maritima. While additional physiological studies will be necessary to determine when the cold-shock response becomes operational in T. maritima, these results suggest that these properties of TmCsps are physiologically relevant and these may be important for adaptation of $T$. maritima to physiologically low temperatures (Phadtare et al., 2003).

\section{Trehalose synthesis upon cold shock}

A protective role of the sugar trehalose in heat and osmotic stress is well established. Recently, its important role in cold adaptation of $E$. coli has been reported (Kandror et al., 2002). Mutant cells deficient in trehalose production show decreased viability at $4^{\circ} \mathrm{C}$, which is restored after mutants are transformed with ots $A$ and ots $B$, genes involved in trehalose synthesis. Upon temperature downshift from 37 ${ }^{\circ} \mathrm{C}$ to $16^{\circ} \mathrm{C}$, cellular level of trehalose increases 8 -fold. The induction of OtsA and OtsB is dependent on RpoS. Their mRNAs show enhanced stability at $16{ }^{\circ} \mathrm{C}$ and contain a 'cold box', characteristic of cold shock mRNAs (Kandror et al., 2002). Although, it is not clear at present exactly how trehalose protects cells against cold shock, various mechanisms are suggested based on its mode of action in other stresses such as heat shock, oxidative damage etc. These include: (i) it prevents denaturation and aggregation of proteins, (ii) it functions as a free radical scavenger in vivo and thus protects against oxidative damage, (iii) it stabilizes cell membranes (Kandror et al., 2002). The elucidation of mechanism of protection by trehalose may 
have broad biological significance, as it is present in variety of organisms including Drosophila, Caenorhabditis elegans and yeasts.

\section{Cold-shock response and global stress response network of cell}

The cellular stress response network is complicated and one system may respond to more than one stress and on the other hand, more than one system may be involved in protecting the cells from a particular stress. Although the cold-shock response machinery seems to be mainly targeted towards reversing the adverse effects of temperature downshift, involvement of CspA homologues and other cold shock proteins in stresses other than cold shock suggests that, regulation and functions of these proteins are intricate. For example, CspC and CspE from $E$. coli regulate the expression of number of RpoSregulated stress proteins such as OsmY, Dps, ProP and KatG, possibly thorough regulation of RpoS itself. These proteins are induced in response to osmotic stress, oxidative stress, or upon stationary phase. CspE and CspC also regulate expression of Universal protein A, UspA, a protein responding to numerous stresses. These findings implicate CspA homologues in the regulation of expression of stress proteins in the complex stress response network of $E$. coli (Phadtare and Inouye, 2001). In addition, CspE has been implicated in number of cellular functions such as, downregulation of poly(A)-mediated 3' to 5' exonucleolytic decay by PNP (Feng et al., 2001), camphor resistance and chromosome condensation (Hu et al., 1996; Sand et al., 2003), and downregulation of $\lambda$ Q-mediated transcription antitermination (Hanna and Liu, 1998). The mechanism(s) by which CspE performs these diverse functions are not defined. In addition, CspA homologues are involved in diverse phenomena such as, response to freezing conditions, stationary phase, osmotic stress, starvation, antibiotic biosynthesis, resistance to antimicrobial peptides, inhibition of replication, heat resistance of the spores, UV sensitivity etc. (Becker et al., 2000; Derzelle et al., 2003; Katzif et al., 2003; Leblanc et al., 2003; Mangoli et al., 2001; Martinez-Costa et al., 2003; Movahedi and Waites, 2002; Porankiewicz et al., 1998; Yamanaka and Inouye, 1997; Yamanaka et al., 2001).

\section{Conclusions and future perspectives}

Cold-shock response is manifested at various levels such as cell membrane, transcription, translation, metabolism etc. The systems such as desaturases, proteins chaperones, trehalose-synthesizing machinery and cold shock proteins that protect the organism from detrimental effects of cold shock are being extensively studied. These studies have made it possible to understand many, though not all, the events that take place inside the cell upon temperature downshift. Cold-shock response system is probably one of the complex stress response systems of bacteria, as in spite of wealth of knowledge accumulated in recent years regarding different aspects of cold-shock response, a number of questions are yet unanswered. For example, it is still not clear why many bacteria have multiple CspA homologues, for example, E. coli has nine CspA homologues. As minimum of four E. coli csp genes had to be deleted before cold sensitivity was manifested, it will be interesting to analyze genome-wide transcriptional profile of cold-shock response of this quadruple deletion strain. The regulation of CspA upon temperature downshift has been a topic of extensive research and debates. Even though cold shock proteins are implicated in number of functions, elaborate research is essential for thorough elucidation of their cellular roles.

Recently, a more general aspect of post-transcriptional control was proposed, which previously was mostly restricted to regulators acting at a single target. According to this concept, global regulators act at the post-transcriptional level and as a result are involved in regulation of number of genes. It was also suggested that the CspA family of cold shock proteins have potential to be global posttranscriptional regulators as they are able to destabilize mRNA secondary structures at low temperatures and thereby allow efficient translation (Nogueira and Springer, 2000). This concept is also supported by involvement of some CspA homologues in regulating other global regulators (see above). However, identification and detail studies of exact cellular targets of these proteins are required before any conclusion can be drawn regarding global regulator status of these proteins.

\section{Acknowledgements}

I greatly appreciate the valuable comments given by Dr. Masayori Inouye. This work was supported by grant from National Institute of Health (GM 19043) to MI.

\section{References}

Achenbach-Richter, L., Gupta, R., Stetter, K.O., and Woese, C.R. 1987. Were the original eubacteria thermophiles? Syst. Appl. Microbiol. 9: 34-39.

Agafonov, D.E., Kolb, V.A., and Spirin, A.S. 2001. Ribosome-associated protein that inhibits translation at the aminoacyl-tRNA binding stage. EMBO Rep. 2: 399-402.

Aguilar, P.S., Cronan, J.E., Jr., and de Mendoza, D. 1998. A Bacillus subtilis gene induced by cold shock encodes a membrane phospholipid desaturase. J. Bacteriol. 180: 2194-2200.

Aguilar, P.S., Hernandez-Arriaga, A.M., Cybulski, L.E., Erazo, A.C., and de Mendoza, D. 2001. Molecular basis of thermosensing: a two-component signal transduction thermometer in Bacillus subtilis. Embo J. 20: 16811691.

Annous, B.A., Becker, L.A., Bayles, D.O., Labeda, D.P., and Wilkinson, B.J. 1997. Critical role of anteiso-C15:0 fatty acid in the growth of Listeria monocytogenes at low temperatures. Appl. Environ. Microbiol. 63: 3887-3894.

Bae, W., Xia, B., Inouye, M., and Severinov, K. 2000. Escherichia coli CspA-family RNA chaperones are transcription antiterminators. Proc. Natl. Acad. Sci. USA. 97: 7784-7789.

Baneyx, F., and Mujacic, M. 2003. Cold-inducible promoters for heterologous protein expression. Methods Mol. Biol. 205: 1-18.

Becker, L.A., Evans, S.N., Hutkins, R.W., and Benson, 
A.K. 2000. Role of sigma(B) in adaptation of Listeria monocytogenes to growth at low temperature. J. Bacteriol. 182: 7083-7087.

Beckering, C.L., Steil, L., Weber, M.H., Volker, U., and Marahiel, M.A. 2002. Genomewide transcriptional analysis of the cold shock response in Bacillus subtilis. J. Bacteriol. 184: 6395-6402.

Berger, F., Morellet, N., Menu, F., and Potier, P. 1996. Cold shock and cold acclimation proteins in the psychrotrophic bacterium Arthrobacter globiformis SI55. J. Bacteriol. 178: 2999-3007.

Berger, F., Normand, P., and Potier, P. 1997. capA, a cspAlike gene that encodes a cold acclimation protein in the psychrotrophic bacterium Arthrobacter globiformis SI55. J. Bacteriol. 179: 5670-5676.

Blaha, G., Wilson, D.N., Stoller, G., Fischer, G., Willumeit, R., and Nierhaus, K.H. 2003. Localization of the trigger factor binding site on the ribosomal $50 \mathrm{~S}$ subunit. J. Mol. Biol. 326: 887-897.

Brandi, A., Spurio, R., Gualerzi, C.O., and Pon, C.L. 1999. Massive presence of the Escherichia coli 'major coldshock protein' CspA under non-stress conditions. Embo J. 18: 1653-1659.

Chamot, D., Magee, W.C., Yu, E., and Owttrim, G.W. 1999. A cold shock-induced cyanobacterial RNA helicase. J. Bacteriol. 181: 1728-1732.

Chamot, D., and Owttrim, G.W. 2000. Regulation of cold shock-induced RNA helicase gene expression in the Cyanobacterium Anabaena sp. strain PCC 7120. J. Bacteriol. 182: 1251-1256.

Cybulski, L.E., Albanesi, D., Mansilla, M.C., Altabe, S., Aguilar, P.S., and de Mendoza, D. 2002. Mechanism of membrane fluidity optimization: isothermal control of the Bacillus subtilis acyl-lipid desaturase. Mol. Microbiol. 45: 1379-1388.

Dammel, C.S., and Noller, H.F. 1995. Suppression of a cold-sensitive mutation in 16S rRNA by overexpression of a novel ribosome-binding factor, RbfA. Genes Dev. 9: 626-637.

Dersch, P., Kneip, S., and Bremer, E. 1994. The nucleoidassociated DNA-binding protein $\mathrm{H}-\mathrm{NS}$ is required for the efficient adaptation of Escherichia coli K-12 to a cold environment. Mol. Gen. Genet. 245: 255-259.

Derzelle, S., Hallet, B., Ferain, T., Delcour, J., and Hols, P. 2003. Improved adaptation to cold-shock, stationaryphase, and freezing stresses in Lactobacillus plantarum overproducing cold-shock proteins. Appl. Environ. Microbiol. 69: 4285-4290.

Donovan, W.P., and Kushner, S.R. 1986. Polynucleotide phosphorylase and ribonuclease II are required for cell viability and mRNA turnover in Escherichia coli K-12. Proc. Natl. Acad. Sci. USA. 83: 120-124.

Drlica, K. 1992. Control of bacterial DNA supercoiling. Mol. Microbiol. 6: 425-433.

Ermolenko, D.N., and Makhatadze, G.I. 2002. Bacterial cold-shock proteins. Cell. Mol. Life. Sci. 59: 1902-1913.

Favaro, R., and Deho, G. 2003. Polynucleotide phosphorylase-deficient mutants of $P$ seudomonas putida. J. Bacteriol. 185: 5279-5286.

Feng, W., Tejero, R., Zimmerman, D.E., Inouye, M., and Montelione, G.T. 1998. Solution NMR structure and backbone dynamics of the major cold-shock protein
(CspA) from Escherichia coli: evidence for conformational dynamics in the single-stranded RNA-binding site. Biochemistry. 37: 10881-10896.

Feng, Y., Huang, H., Liao, J., and Cohen, S.N. 2001. Escherichia coli poly(A)-binding proteins that interact with components of degradosomes or impede RNA decay mediated by polynucleotide phosphorylase and RNase E. J. Biol. Chem. 276: 31651-31656.

Frankenberg, N., Welker, C., and Jaenicke, R. 1999. Does the elimination of ion pairs affect the thermal stability of cold shock protein from the hyperthermophilic bacterium Thermotoga maritima? FEBS Lett. 454: 299-302.

Friedman, D.I., Olson, E.R., Georgopoulos, C., Tilly, K., Herskowitz, I., and Banuett, F. 1984. Interactions of bacteriophage and host macromolecules in the growth of bacteriophage lambda. Microbiol. Rev. 48: 299-325.

Garwin, J.L., and Cronan, J.E., Jr. 1980. Thermal modulation of fatty acid synthesis in Escherichia coli does not involve de novo enzyme synthesis. J. Bacteriol. 141: 1457-1459.

Garwin, J.L., Klages, A.L., and Cronan, J.E., Jr. 1980. Betaketoacyl-acyl carrier protein synthase II of Escherichia coli. Evidence for function in the thermal regulation of fatty acid synthesis. J. Biol. Chem. 255: 3263-3265.

Goldstein, J., Pollitt, N.S., and Inouye, M. 1990. Major cold shock protein of Escherichia coli. Proc. Natl. Acad. Sci. USA. 87: 283-287.

Gombos, Z., Wada, H., and Murata, N. 1992. Unsaturation of fatty acids in membrane lipids enhances tolerance of the cyanobacterium Synechocystis PCC6803 to lowtemperature photoinhibition. Proc. Natl. Acad. Sci. USA. 89: 9959-9963.

Gombos, Z., Wada, H., and Murata, N. 1994. The recovery of photosynthesis from low-temperature photoinhibition is accelerated by the unsaturation of membrane lipids: a mechanism of chilling tolerance. Proc. Natl. Acad. Sci. USA. 91: 8787-8791.

Graumann, P., Schroder, K., Schmid, R., and Marahiel, M.A. 1996. Cold shock stress-induced proteins in Bacillus subtilis. J. Bacteriol. 178: 4611-4619.

Graumann, P., Wendrich, T.M., Weber, M.H., Schroder, K., and Marahiel, M.A. 1997. A family of cold shock proteins in Bacillus subtilis is essential for cellular growth and for efficient protein synthesis at optimal and low temperatures. Mol. Microbiol. 25: 741-756.

Graumann, P.L., and Marahiel, M.A. 1998. A superfamily of proteins that contain the cold-shock domain. Trends Biochem. Sci. 23: 286-290.

Graumann, P.L., and Marahiel, M.A. 1999. Cold shock response in Bacillus subtilis. J. Mol. Microbiol. Biotechnol. 1: 203-209.

Gualerzi, C.O., and Pon, C.L. 1990. Initiation of mRNA translation in prokaryotes. Biochemistry. 29: 58815889.

Gualerzi, C.O., Giuliodori, A.M., and Pon, C.L. 2003. Transcriptional and post-transcriptional control of coldshock genes. J. Mol. Biol. 331: 527-539.

Hanna, M.M., and Liu, K. 1998. Nascent RNA in transcription complexes interacts with $\mathrm{CspE}$, a small protein in E. coli implicated in chromatin condensation. J. Mol. Biol. 282: 227-239.

Hebraud, M., and Potier, P. 1999. Cold shock response and 
low temperature adaptation in psychrotrophic bacteria. J. Mol. Microbiol. Biotechnol. 1: 211-219.

Higgins, C.F., Dorman, C.J., Stirling, D.A., Waddell, L., Booth, I.R., May, G., and Bremer, E. 1988. A physiological role for DNA supercoiling in the osmotic regulation of gene expression in S. typhimurium and E. coli. Cell. 52: 569-584.

Hillier, B.J., Rodriguez, H.M., and Gregoret, L.M. 1998. Coupling protein stability and protein function in Escherichia coli CspA. Fold Des. 3: 87-93.

Hu, K.H., Liu, E., Dean, K., Gingras, M., DeGraff, W., and Trun, N.J. 1996. Overproduction of three genes leads to camphor resistance and chromosome condensation in Escherichia coli. Genetics. 143: 1521-1532.

Inaba, M., Suzuki, I., Szalontai, B., Kanesaki, Y., Los, D.A., Hayashi, H., and Murata, N. 2003. Gene-engineered rigidification of membrane lipids enhances the cold inducibility of gene expression in Synechocystis. J. Biol. Chem. 278: 12191-12198.

Ishizaki-Nishizawa, O., Fujii, T., Azuma, M., Sekiguchi, K., Murata, N., Ohtani, T., and Toguri, T. 1996. Lowtemperature resistance of higher plants is significantly enhanced by a nonspecific cyanobacterial desaturase. Nat. Biotechnol. 14: 1003-1006.

Jiang, W., Fang, L., and Inouye, M. 1996. The role of the 5 '-end untranslated region of the mRNA for CspA, the major cold-shock protein of Escherichia coli, in cold-shock adaptation. J. Bacteriol. 178: 4919-4925.

Jiang, W., Hou, Y., and Inouye, M. 1997. CspA, the major cold-shock protein of Escherichia coli, is an RNA chaperone. J. Biol. Chem. 272: 196-202.

Jones, P.G., VanBogelen, R.A., and Neidhardt, F.C. 1987. Induction of proteins in response to low temperature in Escherichia coli. J. Bacteriol. 169: 2092-2095.

Jones, P. G., Cashel, M., Glaser, G., and Neidhardt, F.C. 1992. Function of a relaxed-like state following temperature downshifts in Escherichia coli. J. Bacteriol. 174: 3903-3914.

Jones, P.G., and Inouye, M. 1994. The cold-shock response--a hot topic. Mol. Microbiol. 11: 811-818.

Kaan, T., Homuth, G., Mader, U., Bandow, J., and Schweder, T. 2002. Genome-wide transcriptional profiling of the Bacillus subtilis cold-shock response. Microbiology. 148: 3441-3455.

Kandror, O., and Goldberg, A.L. 1997. Trigger factor is induced upon cold shock and enhances viability of Escherichia coli at low temperatures. Proc. Natl. Acad. Sci. USA. 94: 4978-4981.

Kandror, O., DeLeon, A., and Goldberg, A.L. 2002. Trehalose synthesis is induced upon exposure of Escherichia coli to cold and is essential for viability at low temperatures. Proc. Natl. Acad. Sci. USA. 99: 9727-9732.

Kaneda, T. 1967. Fatty acids in the genus Bacillus. I. Isoand anteiso-fatty acids as characteristic constituents of lipids in 10 species. J. Bacteriol. 93: 894-903.

Kaneda, T. 1991. Iso- and anteiso-fatty acids in bacteria: biosynthesis, function, and taxonomic significance. Microbiol. Rev. 55: 288-302.

Katzif, S., Danavall, D., Bowers, S., Balthazar, J.T., and Shafer, W.M. 2003. The major cold shock gene, $\operatorname{cspA}$, is involved in the susceptibility of Staphylococcus aureus to an antimicrobial peptide of human cathepsin G. Infect.
Immun. 71: 4304-4312.

Kessel, M., Maurizi, M.R., Kim, B., Kocsis, E., Trus, B.L., Singh, S.K., and Steven, A.C. 1995. Homology in structural organization between E. coli ClpAP protease and the eukaryotic 26 S proteasome. J. Mol. Biol. 250: 587-594.

Kremer, W., Schuler, B., Harrieder, S., Geyer, M., Gronwald, W., Welker, C., Jaenicke, R., and Kalbitzer, H.R. 2001. Solution NMR structure of the cold-shock protein from the hyperthermophilic bacterium Thermotoga maritima. Eur. J. Biochem. 268: 2527-2539.

Krispin, O., and Allmansberger, R. 1995. Changes in DNA supertwist as a response of Bacillus subtilis towards different kinds of stress. FEMS Microbiol. Lett. 134: 129-135.

Leblanc, L., Leboeuf, C., Leroi, F., Hartke, A., and Auffray, Y. 2003. Comparison between $\mathrm{NaCl}$ tolerance response and acclimation to cold temperature in Shewanella putrefaciens. Curr. Microbiol. 46: 157-162.

Lee, S.J., Xie, A., Jiang, W., Etchegaray, J.P., Jones, P.G., and Inouye, M. 1994. Family of the major coldshock protein, CspA (CS7.4), of Escherichia coli, whose members show a high sequence similarity with the eukaryotic Y-box binding proteins. Mol. Microbiol. 11: 833-839.

Lelivelt, M.J., and Kawula, T.H. 1995. Hsc66, an Hsp70 homolog in Escherichia coli, is induced by cold shock but not by heat shock. J. Bacteriol. 177: 4900-4907.

Lopez, M.M., Yutani, K., and Makhatadze, G.I. 2001. Interactions of the cold shock protein CspB from Bacillus subtilis with single-stranded DNA. Importance of the T base content and position within the template. J. Biol. Chem. 276: 15511-15518.

Los, D.A., and Murata, N. 1999. Responses to cold shock in cyanobacteria. J. Mol. Microbiol. Biotechnol. 1: 221230.

Maier, R., Eckert, B., Scholz, C., Lilie, H., and Schmid, F.X. 2003. Interaction of trigger factor with the ribosome. J. Mol. Biol. 326: 585-592.

Mangoli, S., Sanzgiri, V.R., and Mahajan, S.K. 2001. A common regulator of cold and radiation response in Escherichia coli. J. Environ. Pathol. Toxicol. Oncol. 20: 23-26.

Martin, A., Sieber, V., and Schmid, F.X. 2001. In-vitro selection of highly stabilized protein variants with optimized surface. J. Mol. Biol. 309: 717-726.

Martinez-Costa, O.H., Zalacain, M., Holmes, D.J., and Malpartida, F. 2003. The promoter of a cold-shock-like gene has pleiotropic effects on Streptomyces antibiotic biosynthesis. FEMS Microbiol. Lett. 220: 215-221.

Michel, V., Lehoux, I., Depret, G., Anglade, P., Labadie, J., and Hebraud, M. 1997. The cold shock response of the psychrotrophic bacterium Pseudomonas fragi involves four low-molecular-mass nucleic acid-binding proteins. J. Bacteriol. 179: 7331-7342.

Mitta, M., Fang, L., and Inouye, M. 1997. Deletion analysis of $\operatorname{cspA}$ of Escherichia coli: requirement of the AT-rich UP element for $\operatorname{csp} A$ transcription and the downstream box in the coding region for its cold shock induction. Mol. Microbiol. 26: 321-335.

Mizushima, T., Kataoka, K., Ogata, Y., Inoue, R., and Sekimizu, K. 1997. Increase in negative supercoiling of 
plasmid DNA in Escherichia coli exposed to cold shock. Mol. Microbiol. 23: 381-386.

Moll, I., Huber, M., Grill, S., Sairafi, P., Mueller, F., Brimacombe, R., Londei, P., and Blasi, U. 2001. Evidence against an Interaction between the mRNA downstream box and $16 \mathrm{~S}$ rRNA in translation initiation. J. Bacteriol. 183: 3499-3505.

Movahedi, S., and Waites, W. 2002. Cold shock response in sporulating Bacillus subtilis and its effect on spore heat resistance. J. Bacteriol. 184: 5275-5281.

Murata, N., and Wada, H. 1995. Acyl-lipid desaturases and their importance in the tolerance and acclimatization to cold of cyanobacteria. Biochem. J. 308: 1-8.

Nakashima, K., Kanamaru, K., Mizuno, T., and Horikoshi, K. 1996. A novel member of the cspA family of genes that is induced by cold shock in Escherichia coli. J. Bacteriol. 178: 2994-2997.

Nelson, K.E., Clayton, R.A., Gill, S.R., Gwinn, M.L., Dodson, R.J., Haft, D.H., Hickey, E.K., Peterson, J.D., Nelson, W.C., Ketchum, K.A., McDonald, L., Utterback, T.R., Malek, J.A., Linher, K.D., Garrett, M.M., Stewart, A.M., Cotton, M.D., Pratt, M.S., Phillips, C.A., Richardson, D., Heidelberg, J., Sutton, G.G., Fleischmann, R.D., Eisen, J.A., Fraser, C.M., and et al. 1999. Evidence for lateral gene transfer between Archaea and bacteria from genome sequence of Thermotoga maritima. Nature. 399: 323-329.

Neuhaus, K., Rapposch, S., Francis, K.P., and Scherer, S. 2000. Restart of exponential growth of cold-shocked Yersinia enterocolitica occurs after down-regulation of cspA1/A2 mRNA. J. Bacteriol. 182: 3285-3288.

Newkirk, K., Feng, W., Jiang, W., Tejero, R., Emerson, S.D., Inouye, M., and Montelione, G.T. 1994. Solution NMR structure of the major cold shock protein (CspA) from Escherichia coli: identification of a binding epitope for DNA. Proc. Natl. Acad. Sci. USA. 91: 5114-5118.

Nogueira, T., and Springer, M. 2000. Post-transcriptional control by global regulators of gene expression in bacteria. Curr. Opin. Microbiol. 3: 154-158.

Orlova, I.V., Serebriiskaya, T.S., Popov, V., Merkulova, N., Nosov, A.M., Trunova, T.I., Tsydendambaev, V.D., and Los, D.A. 2003. Transformation of tobacco with a gene for the thermophilic acyl-lipid desaturase enhances the chilling tolerance of plants. Plant Cell. Physiol. 44: 447-450.

Panoff, J.M., Corroler, D., Thammavongs, B., and Boutibonnes, P. 1997. Differentiation between cold shock proteins and cold acclimation proteins in a mesophilic gram-positive bacterium, Enterococcus faecalis $\mathrm{JH} 2-2$. J. Bacteriol. 179: 4451-4454.

Perl, D., Welker, C., Schindler, T., Schroder, K., Marahiel, M.A., Jaenicke, R., and Schmid, F.X. 1998. Conservation of rapid two-state folding in mesophilic, thermophilic and hyperthermophilic cold shock proteins. Nat. Struct. Biol. 5: 229-235

Perl, D., and Schmid, F.X. 2001. Electrostatic stabilization of a thermophilic cold shock protein. J. Mol. Biol. 313: 343-357.

Phadtare, S., Alsina, J., and Inouye, M. 1999. Cold-shock response and cold-shock proteins. Curr. Opin. Microbiol. 2: $175-180$.

Phadtare, S., and Inouye, M. 1999. Sequence-selective interactions with RNA by $\mathrm{CspB}, \mathrm{CspC}$ and $\mathrm{CspE}$, members of the CspA family of Escherichia coli. Mol. Microbiol. 33: 1004-1014.

Phadtare, S., and Inouye, M. 2001. Role of CspC and CspE in regulation of expression of RpoS and UspA, the stress response proteins in Escherichia coli. J. Bacteriol. 183: 1205-1214.

Phadtare, S., Inouye, M., and Severinov, K. 2002a. The nucleic acid melting activity of Escherichia coli CspE is critical for transcription antitermination and cold acclimation of cells. J. Biol. Chem. 277: 7239-7245.

Phadtare, S., Tyagi, S., Inouye, M., and Severinov, K. 2002b. Three amino acids in Escherichia coli CspE surface-exposed aromatic patch are critical for nucleic acid melting activity leading to transcription antitermination and cold acclimation of cells. J. Biol. Chem. 277: 4670646711.

Phadtare, S., Hwang, J., Severinov, K., and Inouye, M. 2003. CspB and CspL, thermostable cold-shock proteins from Thermotoga maritima. Genes Cells. 8: 801-810.

Phadtare, S., Yamanaka, K, and Inouye, M 2000. The Cold Shock Response. In: The Bacterial Stress Responses. G. Storz, and R. Hengge-Aronis, ed. ASM Press, Washington DC. P. 33-45.

Polissi, A., De Laurentis, W., Zangrossi, S., Briani, F., Longhi, V., Pesole, G., and Deho, G. 2003. Changes in Escherichia coli transcriptome during acclimatization at low temperature. Res. Microbiol. 154: 573-580.

Porankiewicz, J., and Clarke, A.K. 1997. Induction of the heat shock protein ClpB affects cold acclimation in the cyanobacterium Synechococcus sp. strain PCC 7942. J. Bacteriol. 179: 5111-5117.

Porankiewicz, J., Schelin, J., and Clarke, A.K. 1998. The ATP-dependent Clp protease is essential for acclimation to UV-B and low temperature in the cyanobacterium Synechococcus. Mol. Microbiol. 29: 275-283.

Sakamoto, T., and Bryant, D.A. 1997. Temperatureregulated mRNA accumulation and stabilization for fatty acid desaturase genes in the cyanobacterium Synechococcus sp. strain PCC 7002. Mol. Microbiol. 23: $1281-1292$.

Sakamoto, T., and Murata, N. 2002. Regulation of the desaturation of fatty acids and its role in tolerance to cold and salt stress. Curr. Opin. Microbiol. 5: 208-210.

Sand, O., Gingras, M., Beck, N., Hall, C., and Trun, N. 2003. Phenotypic characterization of overexpression or deletion of the Escherichia coli $\operatorname{crcA}, \operatorname{csp} E$ and $\operatorname{crcB}$ genes. Microbiology. 149: 2107-2117.

Sato, N. 1995. A family of cold-regulated RNA-binding protein genes in the cyanobacterium Anabaena variabilis M3. Nucleic Acids Res. 23: 2161-2167.

Schelin, J., Lindmark, F., and Clarke, A.K. 2002. The clpP multigene family for the ATP-dependent Clp protease in the cyanobacterium Synechococcus. Microbiology. 148: 2255-2265.

Schindelin, H., Marahiel, M.A., and Heinemann, U. 1993. Universal nucleic acid-binding domain revealed by crystal structure of the $B$. subtilis major cold-shock protein. Nature. 364: 164-168.

Schindelin, H., Jiang, W., Inouye, M., and Heinemann, U. 1994. Crystal structure of CspA, the major cold shock protein of Escherichia coli. Proc. Natl. Acad. Sci. USA. 
91: 5119-5123.

Schindler, T., Perl, D., Graumann, P., Sieber, V., Marahiel, M.A., and Schmid, F.X. 1998. Surface-exposed phenylalanines in the RNP1/RNP2 motif stabilize the cold-shock protein CspB from Bacillus subtilis. Proteins. 30: 401-406.

Schnuchel, A., Wiltscheck, R., Czisch, M., Herrler, M., Willimsky, G., Graumann, P., Marahiel, M.A., and Holak, T.A. 1993. Structure in solution of the major cold-shock protein from Bacillus subtilis. Nature. 364: 169-171.

Schroder, K., Graumann, P., Schnuchel, A., Holak, T.A., and Marahiel, M.A. 1995. Mutational analysis of the putative nucleic acid-binding surface of the cold-shock domain, $\mathrm{CspB}$, revealed an essential role of aromatic and basic residues in binding of single-stranded DNA containing the Y-box motif. Mol. Microbiol. 16: 699-708.

Sugino, A., Peebles, C.L., Kreuzer, K.N., and Cozzarelli, N.R. 1977. Mechanism of action of nalidixic acid: purification of Escherichia coli nalA gene product and its relationship to DNA gyrase and a novel nicking-closing enzyme. Proc. Natl. Acad. Sci. USA. 74: 4767-4771.

Suzuki, I., Los, D.A., Kanesaki, Y., Mikami, K., and Murata, N. 2000. The pathway for perception and transduction of low-temperature signals in Synechocystis. Embo J. 19: 1327-1334.

Thompson, M.W., and Maurizi, M.R. 1994. Activity and specificity of Escherichia coli ClpAP protease in cleaving model peptide substrates. J. Biol. Chem. 269: 1820118208.

Toone, W.M., Rudd, K.E., and Friesen, J.D. 1991. deaD, a new Escherichia coli gene encoding a presumed ATP-dependent RNA helicase, can suppress a mutation in $r p s B$, the gene encoding ribosomal protein S2. J. Bacteriol. 173: 3291-3302.

VanBogelen, R.A., and Neidhardt, F.C. 1990. Ribosomes as sensors of heat and cold shock in Escherichia coli. Proc. Natl. Acad. Sci. USA. 87: 5589-5593.

Vasina, J.A., and Baneyx, F. 1997. Expression of aggregation-prone recombinant proteins at low temperatures: a comparative study of the Escherichia coli $\operatorname{csp} A$ and tac promoter systems. Protein Expr. Purif. 9: 211-218.

Wada, H., Gombos, Z., and Murata, N. 1990. Enhancement of chilling tolerance of a cyanobacterium by genetic manipulation of fatty acid desaturation. Nature. 347: 200-203.

Walker, G.C. 1984. Mutagenesis and inducible responses to deoxyribonucleic acid damage in Escherichia coli. Microbiol. Rev. 48: 60-93.

Wang, J.Y., and Syvanen, M. 1992. DNA twist as a transcriptional sensor for environmental changes. Mol. Microbiol. 6: 1861-1866.

Wang, N., Yamanaka, K., and Inouye, M. 1999. Cspl, the ninth member of the CspA family of Escherichia coli, is induced upon cold shock. J. Bacteriol. 181: 1603-1609.

Wassenberg, D., Welker, C., and Jaenicke, R. 1999. Thermodynamics of the unfolding of the cold-shock protein from Thermotoga maritima. J. Mol. Biol. 289: 187-193.

Weber, M.H., Klein, W., Muller, L., Niess, U.M., and Marahiel, M.A. 2001. Role of the Bacillus subtilis fatty acid desaturase in membrane adaptation during cold shock. Mol. Microbiol. 39: 1321-1329.

Weber, M.H., and Marahiel, M.A. 2003. Bacterial cold shock responses. Sci. Prog. 86: 9-75.

Welker, C., Bohm, G., Schurig, H., and Jaenicke, R. 1999. Cloning, overexpression, purification, and physicochemical characterization of a cold shock protein homolog from the hyperthermophilic bacterium Thermotoga maritima. Protein Sci. 8: 394-403.

Willimsky, G., Bang, H., Fischer, G., and Marahiel, M.A. 1992. Characterization of $c s p B$, a Bacillus subtilis inducible cold shock gene affecting cell viability at low temperatures. J. Bacteriol. 174: 6326-6335.

Xia, B., Ke, H., and Inouye, M. 2001a. Acquirement of cold sensitivity by quadruple deletion of the $\operatorname{csp} A$ family and its suppression by PNPase S1 domain in Escherichia coli. Mol. Microbiol. 40: 179-188.

Xia, B., Ke, H., Jiang, W., and Inouye, M. 2001b. The Cold Box stem-loop proximal to the 5'-end of the Escherichia coli cspA gene stabilizes its mRNA at low temperature. J. Biol. Chem. 277: 6005-6011.

Xia, B., Ke, H., Shinde, U., and Inouye, M. 2003. The role of RbfA in 16S rRNA processing and cell growth at low temperature in Escherichia coli. J. Mol. Biol. 332: 575584.

Yamanaka, K., and Inouye, M. 1997. Growth-phasedependent expression of $c s p D$, encoding a member of the CspA family in Escherichia coli. J. Bacteriol. 179: 5126-5130.

Yamanaka, K., Fang, L., and Inouye, M. 1998. The CspA family in Escherichia coli: multiple gene duplication for stress adaptation. Mol. Microbiol. 27: 247-255.

Yamanaka, K., and Inouye, M. 2001a. Selective mRNA degradation by polynucleotide phosphorylase in cold shock adaptation in Escherichia coli. J. Bacteriol. 183: 2808-2816.

Yamanaka, K., and Inouye, M. 2001b. Induction of CspA, an E. coli major cold-shock protein, upon nutritional upshift at 37 degrees C. Genes Cells. 6: 279-290.

Yamanaka, K., Zheng, W., Crooke, E., Wang, Y.H., and Inouye, M. 2001. CspD, a novel DNA replication inhibitor induced during the stationary phase in Escherichia coli. Mol. Microbiol. 39: 1572-1584.

Zeeb, M., and Balbach, J. 2003. Single-stranded DNA binding of the cold-shock protein CspB from Bacillus subtilis: NMR mapping and mutational characterization. Protein Sci. 12: 112-123. 


\section{Further Reading}

Caister Academic Press is a leading academic publisher of advanced texts in microbiology, molecular biology and medical research. Full details of all our publications at caister.com

- MALDI-TOF Mass Spectrometry in Microbiology Edited by: M Kostrzewa, S Schubert (2016) www.caister.com/malditof

- Aspergillus and Penicillium in the Post-genomic Era Edited by: RP Vries, IB Gelber, MR Andersen (2016) www.caister.com/aspergillus2

- The Bacteriocins: Current Knowledge and Future Prospects Edited by: RL Dorit, SM Roy, MA Riley (2016)

www.caister.com/bacteriocins

- Omics in Plant Disease Resistance Edited by: V Bhadauria (2016) www.caister.com/opd

- Acidophiles: Life in Extremely Acidic Environments Edited by: R Quatrini, DB Johnson (2016) www.caister.com/acidophiles

- Climate Change and Microbial Ecology: Current Research and Future Trend

Edited by: J Marxsen (2016)

www.caister.com/climate

- Biofilms in Bioremediation: Current Research and Emerging Technologies

Edited by: G Lear (2016)

www.caister.com/biorem

- Microalgae: Current Research and Applications Edited by: MN Tsaloglou (2016) www.caister.com/microalgae

- Gas Plasma Sterilization in Microbiology: Theory, Applications, Pitfalls and New Perspectives Edited by: H Shintani, A Sakudo (2016) www.caister.com/gasplasma

- Virus Evolution: Current Research and Future Directions Edited by: SC Weaver, M Denison, M Roossinck, et al. (2016) www.caister.com/virusevol

- Arboviruses: Molecular Biology, Evolution and Control Edited by: N Vasilakis, DJ Gubler (2016) www.caister.com/arbo

- Shigella: Molecular and Cellular Biology Edited by: WD Picking, WL Picking (2016) www.caister.com/shigella

-Aquatic Biofilms: Ecology, Water Quality and Wastewater Treatment

Edited by: AM Romaní, H Guasch, MD Balaguer (2016)

www.caister.com/aquaticbiofilms

- Alphaviruses: Current Biology

Edited by: S Mahalingam, L Herrero, B Herring (2016)

www.caister.com/alpha

- Thermophilic Microorganisms

Edited by: F Li (2015)

www.caister.com/thermophile
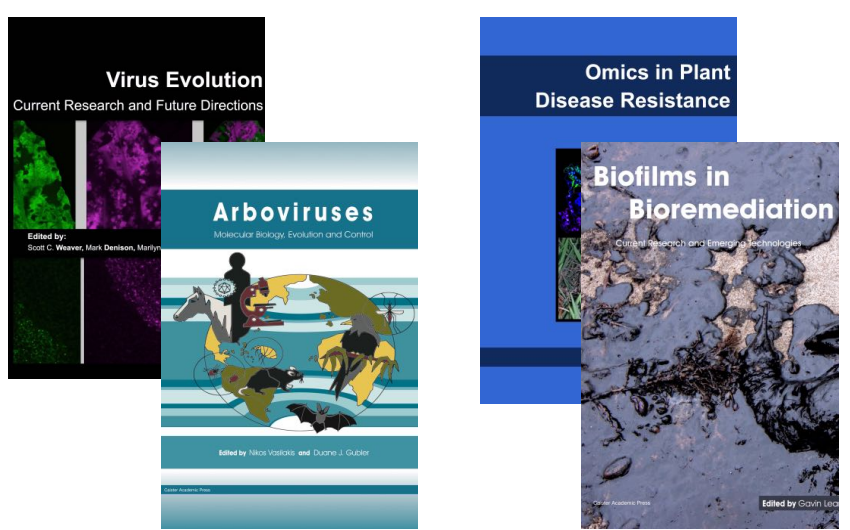
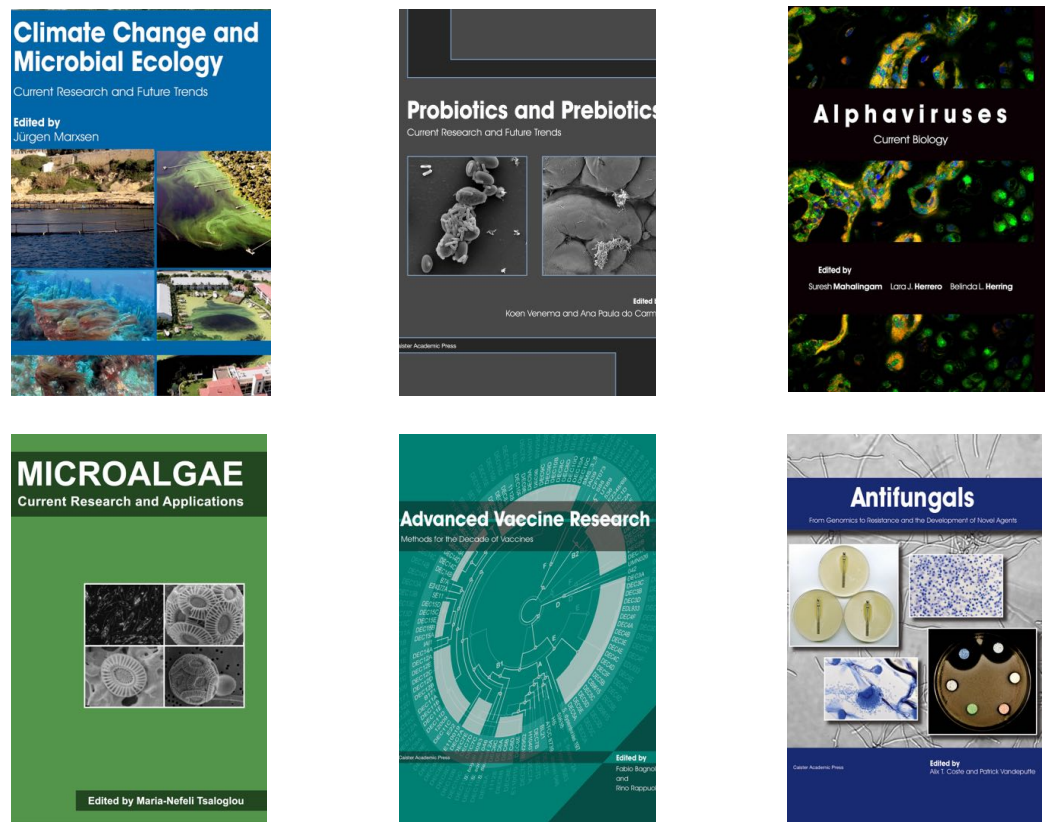

- Flow Cytometry in Microbiology: Technology and Applications Edited by: MG Wilkinson (2015) www.caister.com/flow

- Probiotics and Prebiotics: Current Research and Future Trends Edited by: K Venema, AP Carmo (2015) www.caister.com/probiotics

- Epigenetics: Current Research and Emerging Trends Edited by: BP Chadwick (2015) www.caister.com/epigenetics2015

- Corynebacterium glutamicum: From Systems Biology to Biotechnological Applications

Edited by: A Burkovski (2015)

www.caister.com/cory2

- Advanced Vaccine Research Methods for the Decade of Vaccines

Edited by: F Bagnoli, R Rappuoli (2015)

www.caister.com/vaccines

- Antifungals: From Genomics to Resistance and the Development of Novel Agents

Edited by: AT Coste, P Vandeputte (2015)

www.caister.com/antifungals

- Bacteria-Plant Interactions: Advanced Research and Future Trends Edited by: J Murillo, BA Vinatzer, RW Jackson, et al. (2015) www.caister.com/bacteria-plant

\section{- Aeromonas}

Edited by: J Graf (2015)

www.caister.com/aeromonas

- Antibiotics: Current Innovations and Future Trends

Edited by: S Sánchez, AL Demain (2015)

www.caister.com/antibiotics

- Leishmania: Current Biology and Contro Edited by: S Adak, R Datta (2015) www.caister.com/leish2

- Acanthamoeba: Biology and Pathogenesis (2nd edition) Author: NA Khan (2015)

www.caister.com/acanthamoeba2

- Microarrays: Current Technology, Innovations and Applications Edited by: Z He (2014)

www.caister.com/microarrays2

- Metagenomics of the Microbial Nitrogen Cycle: Theory, Methods and Applications

Edited by: D Marco (2014)

www.caister.com/n2 